\title{
Seria lícito Se Ocupar Da Espada, Quando O Senhor Proclamou Que Quem A Usa Perecerá Por Ela? Tertuliano E A Polêmica do SERViÇo Militar (SÉCUlo III)
}

Ludimila Caliman Campos ${ }^{1}$

\section{RESUMO}

O presente artigo tem por objetivo analisar o pensamento do escritor norteafricano Tertuliano quanto à polêmica do serviço militar cristão. Para tanto, selecionamos duas de suas obras, a saber: De Idololatria e De Corona. A questão levantada por Tertuliano nesses tratados evidencia um cristianismo preocupado não somente com a manutenção do status quo de uma ética cristã, considerando todas as polêmicas que envolviam o serviço militar em si (sacrifícios aos deuses e ao imperador e a obrigação em se torturar e assassinar os inimigos), mas, principalmente, expoe uma necessidade urgente de diferenciação identitária com o seu culto rival, o mitraísmo, o qual arrebanhava grande parte de seus seguidores nas fileiras militares romanas.

PALAVRAS-CHAVE

Império Romano, Tertuliano, Cristianismo, Serviço Militar.

\footnotetext{
${ }^{1}$ Professora titular e pesquisadora na Faculdade Municipal de Ensino Superior de Linhares (FACELI), colaboradora nacional do Laboratório de Estudos sobre o Império Romano (LEIR/UFES/USP) e coordenadora do Laboratório Cultura, Representação e Imagem em Estudo (CRIE/FACELI). Graduada em História (UFES) e Artes (UNIMES). Doutora e mestre em História Social das Relações Políticas pela UFES. $\quad$ E-mail: ludimila.campos@faceli.edu.br. Currículo Lattes: http://buscatextual.cnpq.br/buscatextual/visualizacv.do?id=K4251900T6
} 
No século XVIII, o filósofo Jean-Jacques Rousseau, na obra Do Contrato Social (2011), defendia que o homem é bom por natureza, mas a civilização o corrompe. Ou seja, para além do próprio contrato social, a formação da civilização por si só trazia conflitos para o seio das relações humanas. Todavia, é possível atestar que Rousseau estava equivocado, pois os homens nunca foram o que ele entendia como "bons selvagens". Segundo Fabio Faria e Lawrence H. Keeley, na obra A Guerra Antes Da Civilização: o mito do bom selvagem (2011), o Homo sapiens sapiens nasceu em meio à guerra. Para provar essa hipótese, os autores pesquisam várias marcas arqueológicas que apontam para as guerras na Pré-História. ${ }^{2}$ Reconhece-se, porém, que, ainda que a guerra seja inerente ao ser humano, as civilizações trataram de aperfeiçoá-las, ou seja, a forma de matar mudou no tempo e no espaço.

No caso do Mundo Antigo, mais especificamente de Roma, os conflitos eram muito diversos e a força militar deveras multifacetada. Podemos pontuar que o exército era muito bem estruturado, contando com numerosas divisões e uma hierarquia complexa. Vale destacar que as forças militares eram diferentes se compararmos as províncias com a capital Roma. Enquanto, na cidade de Roma, as três principais guarnições eram divididas em coortes pretorianas, coortes urbanas e vigiles; nas províncias, a divisão era em legiões, forças auxiliares e numeri (Le Bohec, 1994).

As coortes pretorianas funcionavam como guardas para o imperador e proteção da cidade. Apesar de ter a mesma função das coortes pretorianas, as coortes urbanas, formadas por um estrato social mais pobre, desempenhavam, prioritariamente, a função de força policial na cidade. Já os vigiles foram um grupo criado por Augusto em 6 d.C. para exercer as funções de bombeiros e guardas noturnos (Le Bohec, 1994). ${ }^{3}$

No âmbito da força militar provincial, vale ressaltar, as legiões eram compostas por cidadãos romanos e gozavam de maior prestígio social se comparadas às demais funções. Também havia uma força auxiliar, um corpo de tropas regular formada por peregrinos e súditos imperiais que não possuíam cidadania romana - pelo menos até 212 , quando Caracala vai conceder cidadania a todos os habitantes do Império (Gonçalves, 2006). Alguns atuavam de maneira voluntária e, muitas vezes, não remunerada. Ainda havia os numeri, unidades nativas (ou "bárbaras") aliadas, de fora do Império, que

2 Fabio Faria e Lawrence H. Keeley (2011) desenvolveram suas análises a partir de pesquisas arqueológicas feitas a nordeste da Bélgica as quais foram encontradas algumas fortificações bélicas. Os autores notaram que os primeiros registros pré-históricos estão repletos de relatos de cunho bélicos, o que fortalece a tese defendida.

3 Todas as datas deste artigo são d.C., salvo quando expresso em contrário. 
lutavam ao lado das forças regulares em uma base mercenária. Tanto os soldados auxiliares e numeri quanto os legionários podiam compor as fileiras da infantaria pesada, podendo atuar na cavalaria (tanto a blindada quanto a leve), ou ser arqueiros ou fundeiros (Rogan, 2013).

Vale destacar que foi ainda ao final a República que o recrutamento de cidadãos (somente usado para casos de emergência) foi substituído por um exército profissional permanente, composto principalmente por voluntários que, via de regra, cumpriam mandatos de cerca de 20 anos (Goldsworthy, 1998).

No período imperial, mais especificamente durante o reinado de Augusto, havia 28 legiões, consistindo quase que inteiramente de infantaria pesada, com cerca de 5.000 homens cada (total de 125.000) ${ }^{4}$. Já no reinado de Septímio Severo, houve um aumento para 33 legiões com cerca de 5.500 mil homens cada (total de 180.000 homens). As legiões continuaram a recrutar cidadãos romanos, tanto os habitantes da região do Lácio quanto das colônias romanas (Goldsworthy, 1998).

Os militares passavam apenas uma fração de suas vidas em campanha. A maior parte do tempo era gasta em tarefas militares de rotina, como treinamento, patrulhamento e manutenção de equipamentos. Os soldados também tiveram um papel relevante fora da esfera militar. Eles atuavam como força policial para os governadores das províncias, além de trabalharem na construção de diversas obras públicas como fortificações, estradas, pontes, portos, prédios públicos, derrubada de florestas e drenagem de pântanos. Deste modo, o exército foi fundamental na construção de uma infraestrutura militar e civil provincial no Império Romano (Campbell, 2002).

Os soldados desfrutavam de ampla liberdade de culto no Império Romano. Durante o Principado, viu-se um aumento na popularidade dos cultos de mistério entre os militares. Tais cultos, geralmente centrados em uma única divindade, envolviam rituais secretos os quais eram divulgados apenas para os iniciados. Vale frisar que, de longe, o culto mais popular no exército foi o mitraísmo. ${ }^{5}$ Apesar de não ter o mesmo apelo quanto

\footnotetext{
${ }^{4}$ A legião é uma organização militar romana, originalmente, a maior organização permanente. Durante o período republicano, os romanos adotaram o modelo de falanges gregas. Entretanto, por acharam muito pesada para os combates que promoviam nos vales e colinas na Península Itálica, os romanos desenvolveram um novo sistema tático baseado em unidades de infantaria pequenas e flexíveis chamadas manípulos. Cada manípulo contava com 120 homens dividido em 12 grupos e 10 fileiras. Durante a República, cada legião era composta por mais de 3 mil membros. Durante o período imperial, o tamanho das legiões se tornou mais variado (Campbell, 2002).

${ }^{5} \mathrm{O}$ mitraísmo é uma religião de mistérios, de tipo iniciática, calcada na adoração ao deus Mitra. O culto de mistérios em honra a Mitra surgiu por volta do final do século I, como atesta um documento encontrado na Germânia Superior no qual um homem da cavalaria do exército romano, denominado Tácito, dedicou um altar votivo ao deus (Clauss, 1990). Todavia, o deus Mitra remonta aos cultos indianos, tendo sofrido
} 
o mitraísmo, o cristianismo também foi um culto adotado por alguns militares, conforme atesta Tertuliano.

Em termos contextuais, os textos de Tertuliano por nós analisados remontam à transição do século II $^{6}$ para o III, pouco tempo antes da Anarquia Militar ${ }^{7}$. Alguns historiadores apontam que, nesse período, a maior preocupação dos imperadores era a defesa das fronteiras contra as invasões dos bárbaros e a manutenção dos aparados do imperium. De acordo com Ikuo Murone, em um artigo intitulado Tertullian and the Roman Army (1973), os imperadores desse período, mais especificamente Septímio Severo e Caracala, se empenharam em reforçar o exército romano executando dois planos, a saber: a ampliação da cidadania para os soldados e o fortalecimento e controle da disciplina militar. $\mathrm{O}$ primeiro plano visava reforçar o exército com mais soldados romanos e, ainda, ampliar a fonte de receita das províncias. A maior parte dos recrutados eram jovens humiliores. ${ }^{8}$ Do ponto de vista dos humiliores, juntar-se às legiões romanas significava a única chance de ascensão econômica e social. O segundo plano buscava estabelecer a chamada Monarquia Militar, na qual o poder dos imperadores e o êxito do seu exército se pautavam na realização de cerimônias religiosas públicas com a participação direta dos soldados que ali mostravam sua lealdade ao imperador. A

diversas transformações ao longo do tempo, ganhando grande destaque no zoroastrismo persa. Vale frisar que Mitra, enquanto uma divindade indo-iraniana, é conhecido não apenas como o deus dos acordos e tratados, mas do próprio contrato, como atesta Avesta. Em Roma, Mitra ganhou novos atributos, sendo conhecido como um deus onipresente, responsável por ordenar o cosmos (Marques, 2017). No âmbito do Império Romano, o culto mitraísta era uma devoção praticada, exclusivamente, por homens, formado por uma hierárquica bem delimitada e organizada por níveis, que exigia sigilo em torno das suas doutrinas. Os cultos eram realizados em templos em forma de caverna (mithraeum) (Ulansey, 1989).

${ }^{6}$ A O século II ficou conhecido com o período da Pax Romana, definido por alguns autores como o Século de Ouro ou como o Império Humanístico (Petit, 1989). No âmbito religioso, tal momento foi caracterizado pela diversidade de religiões e religiosidades, muitas delas vivenciadas fora dos cultos oficiais do mos maiorum, expressão das novas necessidades surgidas gradativamente em Roma e em seus domínios (Sanzi, 2006). De fato, foi um período de grande inquietação, marcado por um sentimento de insuficiência das religiões tradicionais (Petit, 1989). Além da consolidação do culto ao imperador e da permanência das antigas tradições religiosas, houve uma grande proliferação de religiões orientais, que coexistiram dentro do Império, entre elas o cristianismo.

7 A chamada "Anarquia Militar", "Crise do Terceiro Século" ou "Período dos Imperadores Soldados", começou com o assassinato do imperador Severo Alexandre por suas próprias tropas em 235, indo até 284 com a ascensão do Imperador Diocleciano e sua Tetrarquia, uma nova proposta de governo para o Império. Nesse ínterim, houve, pelo menos, 26 requerentes ao título de imperador, a maioria generais do exército romano, que assumiram o poder imperial sobre todo ou parte do Império, e que foram oficialmente aceitos pelo Senado romano como imperadores durante esse período, assim se tornando imperadores legítimos. Em 268, o Império havia se dividido em três estados concorrentes: o Império Gálico, incluindo as províncias romanas da Gália, Britânia e Hispânia; o Império de Palmira, incluindo as províncias orientais da Síria, Palestina e Egito; e o próprio Império Romano, central e italiano, independente. A crise resultou em mudanças tão profundas nas instituições do Império, na sociedade, na vida econômica e na religião, que a maioria dos historiadores define esse momento como a transição entre os períodos históricos da Antiguidade Clássica para a Antiguidade Tardia (Hekster; Kleijn; Slootjes, 2006; Gonçalves, 2006).

${ }^{8}$ Os humiliores, do latim, "as pessoas mais humildes", era um termo empregado, durante o Alto Império Romano, para fazer referência aos cidadãos livres de baixa renda e status social inferior. 
estratégia era que os imperadores se apoiassem no elemento militar constituído a partir das massas das províncias para se manter no poder e, em troca, as legiões recebessem as benesses do Império, como o aumento do soldo e o status de cidadão (Gonçalves, 2006). Assim, considerando que muitos cristãos estavam diretamente envolvidos com a vida militar romana nessa época, era inevitável que os escritores cristãos se posicionassem sobre o assunto. E Tertuliano, por sua vez, foi o primeiro escritor cristão que assumiu o problema do serviço militar como tema relevante na vida cotidiana dos cristãos.

Filho de um centurião romano do norte da África, segundo Jerônimo, Quintus Septimius Florens Tertulianus, mais conhecido em Língua Portuguesa como Tertuliano, nasceu em Cartago por volta de 160 (Power, 1971). Durante a sua juventude, estudou em Roma, recebendo educação em literatura, em direito e em retórica, sendo fluente em grego e latim. Logo depois de sua conversão, já adulto, Tertuliano se pôs a defender a fé cristã contra pagãos e heréticos. Conhecido por seu extremo rigor, Tertuliano foi autor de diversas obras apologéticas e teológicas, mas não se sabe ao certo se ele chegou a ser um sacerdote ordenado (Garcia, Selvatici 2020). De acordo com Jerônimo (De Viris Illustribus, 53), Tertuliano teria atuado como presbítero na Igreja de Cartago, sob a tutela do bispo Cipriano. Todavia, ao que parece, isso não durou muito. Ainda de acordo com Jerônimo, “[...] desapontado pela inveja e pelo abuso do clero da igreja romana, ele entrou para a doutrina da Montano" (De Viris Illustribus, 53). ${ }^{9} 10$ É possível que a desilusão de Tertuliano com a ekklesia tivesse ocorrido por conta de alguns desentendimentos com as lideranças eclesiásticas locais. ${ }^{11}$ Logo, ele teria visto no montanismo um cristianismo menos institucionalizado e com mais rigor moral. ${ }^{12}$ Tertuliano teria falecido por volta do ano 220 (Dunn, 2005; Decret, 2009).

\footnotetext{
${ }^{9}$ As obras em latim são de tradução da autora do artigo.

10 "Hic cum usque ad mediam aetatem et contumeliis clericorum Romanae Ecclesiae, ad Montani dogma delapsus, in multis libris Novae Prophetiae meminit, specialiter autem adversum Ecclesiam texuit volumina, de pudicitia, de persecutione, de jejuniis, de monogamia, de ecstasi libros sex, et septimum, quem adversum Apollonium composuit." (De Viris Illustribus, 53).

${ }^{11}$ A melhor tradução para a palavra ekklesia na língua portuguesa é o termo —congregação. A utilização do termo -igrejall, apesar de ser mais usual, está relacionada a uma instituição já estruturada politicamente, muito mais identificada com sua formação no medievo e na contemporaneidade do que com o contexto apostólico e pós-apostólico. De fato, a palavra ekklesia é a única que perfeitamente traduz o que eram as comunidades nos primórdios da história cristã.

$12 \mathrm{O}$ montanismo foi um movimento cristão que nasceu na Frígia em 156. Montano, líder e fundador do grupo, era um sacerdote de Cibele que se converteu ao cristianismo. Todavia, o modo pelo qual ele lidava com o agir do Espírito Santo o colocou fora da ekklesia. Logo estabeleceu uma comunidade paralela na qual contava com a ajuda de duas profetisas, Maximila e Priscila, que haviam deixado seus maridos para seguir Montano. Entre os ensinos básicos da organização, denominada também como Nova Profecia, estavam a iminência da parousia e a divindade e atuação do Espírito Santo por meio dos dons espirituais (Boer, 1976).
} 
Dentre as obras de Tertuliano, duas merecem destaque quando ao assunto tratado, a saber: De Idololatria e De Corona Militis.

A primeira obra foi escrita entre 203 e 206 e foi registrada no Codex Agobardinus, datado do século IX. Sua ideia central era abordar como o cristão deveria viver em um mundo onde o paganismo e a adoração aos ídolos estavam incorporados em todos os espaços e ocasiões sociais.

A segunda obra é datada de 202, e foi também registrada no Codex Agobardinus, bem como nos Codex Florentinus e Codex Luxemburgensis, ambos do século XV. Destaca-se por contar, logo no início, a história de um soldado cristão que havia chamado a atenção de todos por se negar a ser coroado. A partir desse relato, Tertuliano se dedica a tecer críticas à prática de serviço militar entre os cristãos.

De Idololatria é considerado o primeiro tratado sistemático sobre a idolatria do início do cristianismo latino. Na obra, Tertuliano inicia seu texto explicando a ideia geral do termo latino idololatria. Segundo ele, a idololatria expressa o que considera ser "a alta culpa no mundo" (De Idololatria, I, 1). ${ }^{13}$ Ademais, de acordo com Tertuliano, o idólatra é uma espécie de assassino, uma vez que ofende e engana a Deus (De Idololatria, I, 2-3). A partir de uma leitura atenta, é possível concluir que Tertuliano traz uma abordagem bastante ampla do termo ao considerar idolatria, simplesmente, qualquer honra dada a seres divinos fora do sistema cristão, sendo essa prática honorífica cúltica ou não. Deste modo, um cristão vagando em um mundo cheio de ídolos precisaria manter a vigilância constante para não cair no pecado de idolatria, oferecendo honras aos deuses (Grillo, 2014).

Tertuliano inova sobre o assunto ao enfatizar que várias práticas de idolatria se colocavam fora da esfera cúltica (De Idololatria, II, 1). De acordo com ele, algumas profissões específicas estavam diretamente associadas às práticas idólatras, a saber: os astrólogos, que praticam as artes das adivinhações fora do âmbito da igreja cristã; os professores, pois quando ensinam história e literatura acabam por pregar e fazer referências sobre os deuses e suas histórias mitológicas; os comerciantes, principalmente aqueles que vendiam incensos e obras de arte, sendo tais denominados "ministros da cobiça”. Nesse contexto, Tertuliano ainda dá um destaque ao serviço militar. Ele afirma o seguinte:

\footnotetext{
13 "Principale crimen generis humani, summus saeculi reatus, tota causa iudicii idololatria." (De Idololatria, I, 1).
} 
(...) também poderemos ver a definição a respeito do serviço militar, que está entre a dignidade e o poder. Mas agora questiona-se se um cristão pode se dedicar ao serviço militar e se um militar pode ser admitido na fé, independentemente de sua hierarquia, mesmo em grau inferior, que não tem necessidade de participar de sacrifícios ou penas capitais. Não há compatibilidade entre o sacramento divino e o humano, entre o estandarte de Cristo e o estandarte do diabo, entre o campo da luz e o campo das trevas, nem pode uma alma dever a dois senhores, Deus e César. E Moisés carregava uma vara, e Arão usava uma fivela, e João [Batista] vestia uma saia de couro e Josué, filho de Num, liderou uma marcha, e as pessoas guerreiam, se quiseres debater. Mas como pode guerrear, ou melhor, como vai servir, ainda que em paz, sem uma espada, aquele que o Senhor tomou? De fato, embora soldados tivessem vindo a João e aceitado suas observações; embora o centurião tenha acreditado, o Senhor, depois, ao desarmar Pedro, desarmou todos os soldados. Não nos é permitido nenhum modo de vida que acarrete atos ilícitos (De Idololatria, XIX). 14

A retórica tertuliana evidencia, logo de início, que militares responsáveis por sacrifícios e penas de morte eram praticantes de idolatria e, por isso, a ocupação desses cargos por cristãos era contrário à fé. De uma maneira geral, o escritor evidencia que o serviço militar deveria ser evitado pelos cristãos não somente porque a guerra não combinava com a vida cristã, mas, principalmente, porque, num contexto de pax deorum,

\footnotetext{
14 "Possit in isto capitulo etiam de militia definitum uideri, quae inter dignitatem et potestatem est. At nunc de isto quaeritur, an fidelis ad militiam conuerti possit et an militia ad fidem admitti, etiam caligata uel inferior quaeque, cui non sit necessitas immolationum uel capitalium iudiciorum. [2] Non conuenit sacramento diuino et humano, signo Christi et signo diaboli, castris lucis et castris tenebrarum; non potest una anima duobus deberi, deo et Caesari. Et uirgam portauit Moyses, fibulam et Aaron, cingitur loro et Iohannes, agmen agit et Iesus Naue, bellauit et populus, si placet ludere. [3] Quomodo autem bellabit, immo quomodo etiam in pace militabit sine gladio, quem dominus abstulit ? Nam etsi adierant milites ad Iohannem et formam obseruationis acceperant, si etiam centurio crediderat, omnem postea militem dominus in Petro exarmando discinxit. Nullus habitus licitus est apud nos illicito actui adscriptus." (De Idololatria, $\mathrm{XIX)}$.
} 
os soldados acabavam sendo obrigados a prestar honras e sacrifícios a César, uma prática dita pagã e idólatra, de acordo com Tertuliano.

Se, no tratado De Idololatria, Tertuliano traz alguns argumentos quanto à participação de cristãos no serviço militar, na obra De Corona Militis, ele aprofunda o assunto. Tertuliano inicia seu texto contando a história de um certo soldado que recusou publicamente as dádivas de Septímio Severo e Caracala, não aceitando se curvar e ser coroado com louros por César ${ }^{15}$. Tal soldado, que se autointitulou cristão, acabou abandonando o serviço militar. De acordo com Tertuliano (De Corona Militis IX), a coroação, por si só, é um ato de veneração pagã, uma vez que nenhum patriarca, nem profeta, nem levita, sacerdote, governante, apóstolo, pregador do evangelho ou bispo teria portado uma coroa. Segundo ele, nem mesmo o templo de Deus foi coroado; como nem a arca da aliança, nem o tabernáculo da testemunha, nem o altar, nem o castiçal foram coroados. Ele conclui afirmando que o único digno de coroação deveria ser Deus. Tertuliano relembra que Jesus havia sido coroado com uma coroa de espinhos pelos soldados romanos, mas os cristãos não deveriam levar isso em consideração, por se tratar alegadamente de uma prática pagã, além de se configurar como uma atitude insolente e desrespeitosa.

Tertuliano prossegue em seu texto argumentando “[...] Que sentido há em discutir o meramente acidental, quando aquilo em que repousa deve ser condenado?" (De Corona Militis, XI, 1). ${ }^{16}$ Ele indaga as contradições em se servir ao exército na medida em que um cristão não poderia coadunar com práticas consideradas nefastas como a utilização de correntes, a prisão, a tortura e o castigo, sabendo que o próprio Cristo teria sofrido nas mãos dos soldados. Tertuliano ainda assevera que a própria vida militar é uma condição de ilegalidade para alguém que pretende se manter no cristianismo. Segundo ele, a guerra em si não é apropriada para um cristão, pois isso implicaria num estado de coisas miseravelmente imperfeitas e aquém das promessas do Evangelho. Tanto é que, em sua

\footnotetext{
${ }^{15}$ A coroa de louros (uma trama composta por folhas de louro e ouro) era um símbolo do triunfo apoteótico oferecido aos generais vitoriosos ao entrarem na cidade de Roma. A origem do uso do adereço remonta à mitologia grega, mais especificamente a história de Dafne. Na história, Dafne se transformava em um loureiro para fugir de Apolo, que estava apaixonado por ela. Apesar da transformação em loureiro, Apolo resolve levar a ninfa consigo, fazendo-a seu símbolo desde então. Por esse motivo, na arte grega, Apolo era, costumeiramente, representado com uma coroa de louros. Em Atenas, muitos nobres também faziam uso do da coroa de louros, por simbolizar distinção e glória, ainda que tenha sido substituída, algumas vezes, por ramos de oliveira (Smith, 2014).

16 "Quale est alioquin de accidentibus retractare, cum a praecedentibus culpa sit?" (De Corona Militis, XI, $1)$.
} 
opinião, os integrantes do exército romano que se convertessem ao cristianismo deveriam abandonar a carreira militar imediatamente.

No capítulo seguinte, Tertuliano volta a discutir a questão relacionada às coroas:

[...] Mas primeiro falemos da coroa. O louro é sagrado para Apolo ou Baco: para o primeiro, como o deus das flechas; para o segundo, como o deus dos triunfos. Assim Cláudio ensina quando diz que os soldados costumam ser coroados com murtas. De fato, os romanos adotaram a murta de Vênus, a mãe dos descendentes de Enéias e a amante de Marte, por causa de Ilia e de Rômulo romano. [...] Quando os militares são coroados com folhas de oliveira, se adora Minerva, que é igualmente a deusa dos combates, e que usa uma coroa feita com folhas de oliveira, por causa da paz que fez com Netuno. A esse respeito, a superstição da guirlanda militar está por toda parte, cheia de contaminação e difamação. E é ainda mais impura, em razão disso. Bem! O que achamos da celebração anual de votos, a primeira perante os césares, a segunda perante os capitéis? Ocorre primeiro na parte do acampamento onde fica a tenda do general e depois nos templos. Além dos juramentos nesses lugares, observe-se também o juramento com as seguintes palavras: "Juramos que você, ó Júpiter, que terá um boi com chifres decorados com ouro". O que significa esse enunciado? Sem dúvida a negação (de Cristo). Embora o cristão, nesses lugares, não diga nada com a boca, ele responde com uma coroa na cabeça. O soldado é ordenado a se apresentar com a mesma coroa de louros quando recebe uma gratificação. É certo que a idolatria não é gratuita: "Ela ainda vende a Cristo por um pouco de ouro, como no passado fez Judas. Você não pode servir a Deus e a Mamom (Mt. 6:24), mas teria que dedicar suas energias a Mamom e se afastar de Deus? Você pode dar a César as coisas que são de César, e a Deus as coisas que são de Deus (Mt. 22:21), 
Mare Nostrum, ano 2021, v. 12, n. 2

não apenas para não oferecer o ser humano a Deus, mas também para tirar o denário de César? O louro do triunfo é feito de folhas ou cadáveres? É adornado com fitas ou túmulos? É enfeitado com unguentos ou com lágrimas de esposas e mães? Alguns podem também até ser cristãos; pois Cristo também está entre os bárbaros. Quem carregou (uma coroa dessas) em sua cabeça, não guerreou contra si mesmo?

Dá-se o nome de castrenses às coroas que os césares distribuem para os seus guardas particulares em certas solenidades. Nesse contexto, eles se tornam um soldado e um servo (dele); mas, no caso do soldado cristão, se ele é dos dois senhores ao mesmo tempo, de Deus e César, certamente, não é de César, já que serve a Deus, uma vez que oferece a si mesmo com orações ao alto. (De Corona Militis, XII). ${ }^{17}$

No trecho acima, Tertuliano associa as pompas dos soldados aos deuses pagãos e as honras ao Império e seu imperador. Logo, para além da ideia de que os cristãos não poderiam compor as fileiras do exército, pois a prática militar não se coadunava com a ética cristã de paz e combate à violência, ele ainda associa essa prática ao fato de que os rituais militares estarem repletos de práticas idólatras e honras aos deuses pagãos e ao

\footnotetext{
17 "Sed et de corona prius dicamus. Laurea ista Apollini uel Libero sacra est, illi ut deo telorum, huic ut deo triumphorum. Sic docet Claudius, cum et myrto ait milites redimiri solere: Veneris enim myrtus, matris Aeneadarum, etiam amiculae Martis, per Iliam et Romulos Romanae. Sed ego Venerem non credo ex hac parte cum Marte Romanam, qua pelicis dolor est. Cum et olea militia coronatur, ad Mineruam est idololatria, armorum aeque deam, sed et pace cum Neptuno inita ex hac arbore coronatam. In his erit serti militaris superstitio, ubique polluta et polluens omnia. Quae iam polluantur et causis. Ecce annua uotorum nuncupatio: quid uidetur? Prima in principiis, secunda in capitoliis. Accipe, post loca, et uerba: Tunc tibi, Iuppiter, bouem cornibus auro decoratis uouemus esse futurum. Cuius sententiae uox est? Vtique negationis. Etiam si tacet illic christianus ore, coronatus capite respondit. Eadem laurea in donatiui dispensationem denuntiatur. Plane non gratuita idololatria, aliquibus aureis uenditans Christum, ut argenteis Iudas. Hoc erit Non potestis Deo seruire et mammonae, mammonae manum tradere et Deo absistere? Hoc erit Reddite quae sunt Caesaris Caesari et quae Dei Deo, nec hominem Deo reddere et denarium Caesari auferre? Triumphi laurea foliis struitur an cadaueribus? lemniscis ornatur an bustis? unguentis delibuitur an lacrimis coniugum et matrum? Fortasse quorundam et christianorum: et apud bárbaros enim Christus. Qui hanc portauerit in capite causam, nonne et ipse pugnauit? Est et alia militia, regiarum familiarum. Nam et castrenses appellantur, munificae et ipsae sollemnium Caesarianorum. Sed et tu proinde miles ac seruus alterius, et si duorum, Dei et Caesaris, certe tunc non Caesaris, cum te Deo debes, etiam in communibus, credo, potiori." (De Corona Militis, XII).
} 
imperador. Para rechaçar a ideia de que os soldados poderiam adotar atitudes venerativas diante do imperador, Tertuliano faz uma interpretação da fala de Jesus na passagem bíblica em que fariseus e herodianos questionam Jesus quanto ao pagamento de impostos. ${ }^{18}$

No último capítulo de De Corona Militis, Tertuliano fortalece seu argumento ao destacar que o exército estava repleto de seguidores de Mitra e que, por isso, não deveria ter suas fileiras ocupadas por cristãos.

Companheiro deste soldado, envergonhe-se! Você não merece ser julgado; você deve ser condenado como um soldado de Mitra que, enquanto é iniciado em um antro, um verdadeiro campo de trevas, vive como se quisesse falsear o martírio, e recebe a coroa que lhe é apresentada por uma espada e colocada na cabeça. Então, uma mão se coloca sobre a cabeça, o que o adverte a deixá-la (a coroa) a cair da cabeça, talvez jogá-la por cima do ombro, repetindo: Mithras é a minha coroa. Desde então, ele nunca usou uma coroa. Este sinal atesta sua eleição, se por acaso o sujeitar à prova do juramento: que ele rejeita a coroa, que proclama que está inteiramente em seu deus, acredita-se imediatamente que ele é um

\footnotetext{
18 "Depois eles lhe enviaram alguns dos fariseus e dos herodianos para o apanhar em alguma palavra. Estes, vindo a ele, disseram: Mestre, sabemos que és verdadeiro, e não se te dá de ninguém; porque não te deixas levar de respeitos humanos, mas ensinas o caminho de Deus segundo a verdade; é lícito ou não pagar tributo a César? Pagaremos ou não pagaremos? Mas Jesus, percebendo a hipocrisia deles, respondeu-lhes: Por que me experimentais? trazei-me um denário para eu vê-lo. Eles lho trouxeram. Perguntou-lhes: De quem é esta efígie e inscrição? Responderam-lhe: De César. Disse-lhes Jesus: Dai, pois, a César o que é de César, e a Deus o que é de Deus. Admiravam-se muito dele" (Mc. 12:13-17). "Então os fariseus se retiraram e consultaram como apanhariam a Jesus em alguma palavra. Enviaram os seus discípulos, juntamente com os herodianos, a perguntar: Mestre, sabemos que és verdadeiro e que ensinas o caminho de Deus segundo a verdade, e não se te dá de ninguém, porque não te deixas levar de respeitos humanos; dize-nos, pois, qual é o teu parecer; é lícito ou não pagar o tributo a César? Porém Jesus, tendo percebido a malícia deles, respondeu-lhes: Por que me experimentais, hipócritas? Mostrai-me uma moeda de tributo. Trouxeram-lhe um denário. Ele perguntou: De quem é esta efígie e inscrição? Responderam: De César. Então lhes disse Jesus: Dai, pois, a César o que é de César, e a Deus o que é de Deus. Ao ouvirem isto, admiraram-se e, deixando-o, foram-se" (Mt. 22:15-22). " Observando-o, enviaram-lhe emissários, que se fingiram justos, para o apanhar em alguma palavra, de modo que o pudessem entregar à jurisdição e à autoridade do governador. E perguntaram-lhe: Mestre, sabemos que falas e ensinas retamente, e não te deixas levar de respeitos humanos, mas ensinas o caminho de Deus segundo a verdade; é-nos lícito ou não pagar tributo a César? Mas Jesus, percebendo a astúcia deles, disse-lhes: Mostrai-me um denário. De quem é a efígie e a inscrição que ele tem? Responderam: De César. Disse-lhes Jesus: Dai, pois, a César o que é de César, e a Deus o que é de Deus. Não puderam apanhá-lo em palavra alguma diante do povo; e maravilhados da sua resposta, calaram-se" (Lc. 20:20-26).
} 
soldado de Mitra. Vamos reconhecer, aqui, as habilidades do diabo em usurpar algumas das coisas divinas e confundir a fé dos discípulos. (De Corona Militis, $\mathrm{XV}, 3-4){ }^{19}$

No trecho acima, é possível perceber que havia uma clara competição entre os adoradores de Cristo e os adoradores de Mitra. Tal competição ocorria, pois o mitraísmo, além de ter sido um dos cultos mais populares no Império durante os séculos II e III, era estrangeiro e oriental, tal qual o cristianismo, logo, seu concorrente direto. Se não bastasse, conforme assevera o próprio Tertuliano, na obra De Praescriptione Haereticorum (XL), o culto de Mitra adotava rituais deveras semelhantes aos empreendidos pelos cristãos. De acordo com o próprio Tertuliano, o culto mitraico perverteria a verdade do cristianismo por meio dos seus ritos místicos de seus ídolos imitando e distorcendo as escrituras e os rituais cristãos, como o baptismus e a eucharistia. Vale ressaltar que Justino, o Mártir, ainda no século II, também acusou os mitraístas de imitação. ${ }^{20}$

Enquanto, em sua retórica acerca das religiões tradicionais romanas, Tertuliano não se preocupou em acusá-las abertamente, quando este tratou do culto de Mitra é possível perceber não somente um confronto direto, mas também uma competição de caráter distintivo. ${ }^{21}$ Por seu turno, o que estaria por detrás dessa competição era um claro jogo identitário delimitado pela oposição binária “nós" e “outros" (Silva, 2000). Adotando as tipologias de competição religiosa de Hans Mol (1972), podemos concluir que se trata de um processo de comparação entre grupos que produz uma dinâmica

\footnotetext{
19 "Quem et bonus miles eligendo in caelesti ordinatione profecit. Erubescite, commilitones eius, iam non ab ipso iudicandi, sed ab aliquo Mithrae milite. Qui cum initiatur in spelaeo, in castris uere tenebrarum, coronam interposito gladio sibi oblatam quasi mimum martyrii, dehinc capiti suo accommodatam, monetur obuia manu a capite pellere et in humerum, si forte, transferre, dicens Mithran esse coronam suam. Atque exinde numquam coronatur, idque in signum habet ad probationem sui, sicubi temptatus fuerit de sacramento, statimque creditur Mithrae miles, si deiecerit coronam, si eam in deo suo esse dixerit. Agnoscamus ingenia diaboli, idcirco quaedam de diuinis affectantis ut nos de suorum fide confundat et iudicet." (De Corona Militis, XV, 3-4).

${ }^{20}$ Na obra Apologia Prima (66:3-4), Justino afirma que "Os apóstolos, na história escrita por eles, chamada de Evangelhos, nos entregaram o que lhes foi ordenado - que Jesus tomou pão, agradeceu, disse: "Fazemos isso em memória de Mim"; este "é o meu corpo" e, da mesma maneira, "tendo tomado o cálice e dando graças, disse: Este é o meu sangue" (Lucas 22:19). Os demônios, por sua vez, têm imitado [nossa eucaristia] por meio dos cultos de mistérios de Mitra. Nesses, o pão e o copo de água são usados com encantamentos em ritos místicos destinados para aqueles que estão num processo de iniciação. "

${ }^{21}$ Sobre esse assunto, vale destacar que Tertuliano, na obra Apologeticum, busca criar uma identidade coletiva por meio da reafirmação dos dogmas cristãos e modelos de conduta que deveriam ser seguidos, sendo que uma das formas para se fazer isso era por meio do resgate de elementos da história, cultura práticas religiosas romanas (Oliveira, 2015).
} 
competitiva na qual cada um deles tenta aprimorar suas identidades ${ }^{22}$. Numa tentativa de alcançar uma posição comparativamente superior, e sem espaço para negociação, os grupos se auto valorizam a partir da estigmatização do outro. Por outro lado, quando a ação de um grupo pela distinção positiva é frustrada ou, de alguma forma, ativamente impedida por um grupo externo, promove-se um conflito aberto e hostilidade entre dos grupos (Seul 1999). Considerando que as tradições e instituições religiosas resistem às mudanças e às negociações sociais exatamente para proporcionar aos indivíduos âncoras mais seguras para autoreferência, investir contra a integridade identitária seria agredir a estabilidade da própria religião. Deste modo, a agenda retórica de Tertuliano estava voltada para atacar o culto mitraico a fim de proteger o culto cristão de uma instabilidade identitária preservando, assim, seus rituais, doutrinas, estruturas morais e papeis sociais. ${ }^{23}$ Não é à toa que Tertuliano acusa os mitraístas exatamente de imitadores de rituais de passagem - baptismus e eucaristia -, isso porque, os ritos são espaços privilegiados para a socialização religiosa que contribuem para a coesão das identidades coletivas.

Ademais, David Rankin destaca que, tanto em De Corona Militis quanto em De Idololatria, Tertuliano emprega o vocábulo castra (campo) com um relevante significado eclesiológico. $\mathrm{O}$ aumento da militarização nas províncias imperiais romanas significou um aumento na pressão para que os cristãos tomassem algumas decisões quanto a assumir a identidade cristã ou seguir as leis romanas e portar armas. Nesse contexto, muitos soldados se convertiam ao mitraísmo e, alguns outros, ao cristianismo. Todavia, Tertuliano, enquanto portador de uma retórica eclesiástica, buscou delimitar uma fronteira entre a ekklesia (campo da luz) e os seus oponentes (o mundo) enquanto campo das trevas.

Deste modo, é possível concluir que Tertuliano se colocou contrário à participação de cristãos no exército romano - algo que já ocorria - por dois motivos simples e um complexo. O primeiro, simples, era que, para ele, um soldado cristão não conseguiria se negar a prestar honras e sacrifícios aos deuses e ao imperador nas cerimônias oficiais, e

\footnotetext{
${ }^{22}$ Hans Mol (1972) discute o potencial integrador e desintegrador da religião ao desenvolver algumas hipóteses sobre os vários modos pelos quais as instituições e ideologias religiosas ocidentais competem entre si. O autor sugere que isso ocorre em pelo menos três níveis: no nível de lealdade institucional, quando as organizações religiosas que tiveram que competir invariavelmente se mostraram mais aptas para a adesão; no nível da formação da identidade, quando as orientações religiosas ocidentais do tipo sectário geralmente competem com foco na identidade; e, por fim, no nível da ideologia, quando as doutrinas da salvação religiosa ocidental tiveram a vantagem competitiva por meio do equilíbrio entre a ancoragem emocional e explicação abrangente.

${ }^{23}$ De acordo com Garcia e Selvatici (2020), Tertuliano, na obra Adversus Marcionem, se utiliza de estratégias semelhantes de desconstrução identitária ao se referir a figura Marcião.
} 
Mare Nostrum, ano 2021, v. 12, n. 2

o segundo porque havia o problema do próprio oficio do soldado em guerra - a função de torturar e a assassinar o inimigo - que não se coadunava com a ética cristã. O motivo mais complexo, por seu turno, seria a necessidade de diferenciação identitária entre o cristianismo e o mitraísmo. De fato, o discurso de Tertuliano, confirmado também por Justino, o Mártir, evidencia que havia um problema identitário grave no cristianismo, possivelmente porque os praticantes do mitraísmo e do cristianismo eram confundidos entre si pelos romanos. Logo, o mitraísmo, enquanto sistema de crenças organizado com uma grande rede de adeptos nas administrações militar e imperial, representava, por si só, um grande desafio à formação identitária da emergente ekklesia cristã.

Recebido: $27 / 01 / 2021$

Aprovado: 04/05/2021 


\section{REFERÊNCIAS BIBLIOGRÁFICAS}

Bíblia de Jerusalém, (2006). Tradução do texto em língua portuguesa e coordenação por Gilberto da Silva Gorgulho, Ivo Storniolo e Ana Flora Anderson. São Paulo: Paulus,

Bíblia, (1994). Português-Grego. Tradução do texto em língua portuguesa de Ferreira de Almeida e NTLH. Novo Testamento Interlinear Grego-Português. São Paulo: Sociedade Bíblica do Brasil.

Boer, H. R. (1976). A Short History of the Early Church. Wm. B. Eerdmans: Grand Rapids, Michigan.

Campbell, J. B. (2002). War and Society in Imperial Rome 31 BC-AD 284. London: Routledge.

Clauss, M. (1990). The Roman Cult of Mithras: The God and His Mysteries. New York: Routledge.

Decret, F. (2009). Early Christianity in North Africa. Cambridge: Cambridge University Press.

Dunn, M. (2005). Rhetoric and Tertullian's De virginibus velandis. Vigiliae Christianae, BRILL, v. 59, n. 1.

Garcia, W. F. Selvatici, M. (2020). Construindo as bases de uma identidade cristã: o discurso de Tertuliano de Cartago sobre Marcião, em Adversus Marcionem. Romanitas. n. 15.

Goldsworthy, A. K. (1998). The Roman Army at War: 100 BC-AD 200. Oxford: University Press.

Gonçalves, A. T. M. (2006). Os Severos e a Anarquia Militar. In: SILVA, G. V. MENDES, N. M (Org). Repensando o Império Romano: perspectiva socioeconômica, política e cultural. Rio de Janeiro: Mauad. GRILLO, J. (2014). Worship and idolatry in the book of Daniel through the lens of Tertullian's De idololatria'. In: MACDONALD, N.; BROWN, K. Monotheism in Late Prophetic and Early Apocalyptic Literature. v. 3. Tübingen: Mohr Siebeck. (pp. 247-62).

Hekster, O.; Kleijn, G.; Slootjes, D. (2006). Crises and the Roman Empire: Proceedings of the Seventh. Workshop of the International Network Impact of Empire. Leiden and Boston: Brill.

Jean Danielou, (2006). Los orígenes del cristianismo latino. Madrid: Cristiandad.

Justin Martir, (1996). The First and Second Apologies. In: BARNARD, L. (Trad.). St. Justin Martyr: The First and Second Apologies. New York: Paulist Press. 
Le Bohec, Y. (1994). The Imperial Roman Army. London: B.T. Batsford Ltd.

Marques, J. M. A. O exército romano e as representações do deus Mitra: possibilidades interpretativas. 2017. 115 f. Dissertação (Mestrado Acadêmico ou Profissional) Universidade Estadual do Ceará.

Mol, H. (1972). Religion and Competition. Sociology of Religion. v 33, n. 2. (pp. 67-73).

Murone, I. (1973), Tertullian and the Roman Army. ThStJ 12. (pp. 24-28).

Oliveira, T. (2015). Identidades cristãs na Antiguidade Tardia: ressignificações dos valores e práticas romanas na Apologia de Tertuliano. Revista Alétheia, v. 10, n. 1 (14). (pp. 60-68).

Petit, Paul. (1989). A Paz Romana. São Paulo: Pioneira (Edusp).

Power, V. (1971). Tertullian: Father of Clerical Animosity toward the Theatre. Educational Theatre Journal. The Johns Hopkins University Press, v. 23, n. 1, (pp. 36-50).

Rankin, D. (2004). Tertullian and the Church. London: Routledge.

Rogan, J. (2013). Roman Provincial Administration. Bristol: Bristol Classic Press.

Rostovtzeff, M. (1977). História de Roma. Rio de Janeiro: Zahar.

Rousseau, J. J. (2011). Do contrato social. São Paulo: Companhia das Letras.

San Jerónimo, (1998). De Viris illustribus. Serie Santos Padres. № 55. Sevilla: Editorial Apostolado Mariano.

Sanzi, E. (2006). Cultos orientais e magia no mundo helenístico-romano: modelos e perspectivas metodológicas. Fortaleza: EdUECE.

Seul, J. R. (1999). Ours is the Way of God': Religion, Identity, and Intergroup Conflict. Journal of Peace Research. v. 36, n. 5. (pp. 553-569).

Silva, G. V. (2006). A relação Estado/Igreja no Império Romano (séculos III e IV). In: SILVA, G. V. MENDES, N. M (Org). Repensando o Império Romano: perspectiva socioeconômica, política e cultural. Rio de Janeiro: Mauad.

Silva, T. T. (2000). Identidade e diferença: a perspectiva dos estudos culturais. Rio de Janeiro: Vozes.

Smith, S. D. (2014). Man and Animal in Severan Rome: The Literary Imagination of Claudius Aelianus. Cambridge: Cambridge University Press.

Tertullian, (1842). De Praescriptione Haereticorum. Traduzido por C. Dodgson. Apologetic and Practical Treatises.

Tertullian, (1842). De Corona Militis. Traduzido por C. Dodgson. Apologetic and Practical Treatises. 
Ludimila Caliman Campos, Seria lícito se ocupar da espada...

Tertullian, (1842). De Idololatria. Traduzido por C. Dodgson. Apologetic and Practical Treatises.

Ulansey, (1989). The Origins of the Mithraic Mysteries. Oxford: Oxford University Press. 
Mare Nostrum, ano 2021, v. 12, n. 2

\title{
Would It Be Lawful To Take The Sword, When The Lord Proclaims Whoever Uses The Sword Will Perish For It? Tertullian And Military SERVice Controversy (3RD CENTURY)
}

\author{
Ludimila Caliman Campos
}

\section{ABSTRACT}

This article aims to analyze the thinking of the North African writer Tertullian regarding the controversy of Christian military service. For that, we selected two of his works, namely: De Idololatria and De Corona. The question raised by Tertullian in these treaties shows a Christianity concerned not only with maintaining the status quo of a Christian ethic, considering all the controversies surrounding military service itself (sacrifices to the gods and the emperor and the obligation to torture and murder enemies), but, above all, it exposes an urgent need for identity differentiation with its rival cult, Mithraism, which gathered a large part of its followers in the Roman military ranks.

KEYWORDS

Roman Empire, Tertullian, Christianity, Military service. 